\title{
Nutrient dynamics study of overlying water affected by peroxide-treated sediment
}

\author{
Niamul Haque ${ }^{1}$ and Sung-Hyun Kwon ${ }^{2 *}$
}

\begin{abstract}
Background: Loading of excess nutrient via bioremediation of polluted sediment to overlying water could trigger anoxia and eutrophication in coastal area. The aim of this research was to understand the changes of overlying water features such as dissolved oxygen (DO); pH; oxidation reduction potential (ORP); chlorophyll-a (Chl-a); and nitrogen nutrients ammonia $\left(\mathrm{N}_{-} \mathrm{NH}_{4}{ }^{+}\right)$, nitrate $\left(\mathrm{N}_{-} \mathrm{NO}_{3}{ }^{-}\right)$, and nitrite $\left(\mathrm{N}-\mathrm{NO}_{2}^{-}\right)$when the sediment was not treated (control) and treated by calcium peroxide for 5 weeks.

Methods: The water samples were analyzed for measuring physical and chemical properties along with the sediment analyzed by polymerase chain reaction (PCR) including denaturing gradient gel electrophoresis (DGGE) for identifying the phylogenetic affiliation of microbial communities.

Results: Results showed that due to the addition of calcium peroxide in sediment, the overlying water exposed the rise of dissolve oxygen, $\mathrm{pH}$, and ORP than control. Among the nitrogen nutrients, ammonia inhibition was higher in calcium peroxide treatment than control but in case of nitrate inhibition, it was reversed than control. Chlorophyll- $a$ was declined in treatment column water by $30 \%$ where it was $20 \%$ in control column water. Actibacter and Salegentibacter group were detectable in the calcium-peroxide-treated sediment; in contrary, no detectable community ware found in control sediment. Both phylogenetic groups are closely related to marine microflora.

Conclusions: This study emphasizes the importance of calcium peroxide as an oxygen release material. Interaction with peroxide proved to be enhancing the formation of microbial community that are beneficial for biodegradation and spontaneity of nutrient attenuation into overlying water.
\end{abstract}

Keywords: Oxygen release, Calcium peroxide, Bacteria, Anoxia, Remediation, Nitrification

\section{Background}

Marine sediments in coastal sites usually contaminated by pollutants from a wide variety of anthropogenic sources, such as wastewater effluents, industrial sewage, and large amount of aquaculture activities, are posing extensive dangers to the environment (Zhang et al. 2015). Researchers have proven that the overlying water and sediment was the major object of contaminants like excess nutrient loading and stinky odor, where decomposition of organic matter and onsite nitrification might greatly contribute to anoxia of the water body (Wu et al. 2012). However, the depletion of oxygen in the sediment may be contributed to the release of $\mathrm{N}$ nutrient from the

\footnotetext{
* Correspondence: shkwon@gnu.ac.kr

${ }^{2}$ Department of Marine Environmental Engineering, College of Marine Science, Engineering Research Institute (ERI), Gyeongsang National University, Cheondaegukchi-Gil 38, Tongyeong, Gyeongnam 650-160, Republic of Korea
} Full list of author information is available at the end of the article sediment into the water column. So, increased $\mathrm{N}$ nutrient concentration and algal blooms leads to more severe anoxia, and apparently, there is a mutual enhanced effect between these two processes (Liu et al., 2016a, b). However, the remediation of contaminated sediment has gained much attention in the past decade since it has been recognized that substantial improvement in the quality of the overlying water often cannot be achieved without appropriate treatment of contaminated sediment. Thus, great efforts have been made in recent years in exploring the effective remediation approaches for the decontamination of marine sediments (Veetil et al. 2013; Asaoka et al. 2015). Several types of chemicals or biological agents have been applied for in situ sediment dealing through directly injecting into the contaminated sediment for the purposes of odor control, nutrient inactivation, and organic contaminant bioremediation 
(Nykanen et al. 2012; Perelo 2010). Calcium peroxide $\left(\mathrm{CaO}_{2}\right)$ is the most used agent injected into the sediment being treated as it has gained great attention to promote contaminant biodegradation (Hanh et al. 2005). Due to the immediate reaction with water, $\mathrm{CaO}_{2}$ has a superior characteristic in improving the oxygen concentration rapidly despite the rise of the $\mathrm{pH}$ value of water. In addition, acid volatile sulfide that exists in sediments can be oxidized to sulfate through the autotrophic denitrification process, resulting in sulfide decrease and odor suppression (Liu et al. 2015). Moreover, improved dissolved oxygen can stimulate aerobic respiration of the microorganism in the sediment and reduce the formation of $\mathrm{H}_{2} \mathrm{~S}$ and $\mathrm{NH}_{3}$, etc. and an aerobic membrane is formed to prevent pollutants in the sediment from releasing into the overlying water. So far, few researches have been reported by the method of using oxygen release material to control $\mathrm{N}$ nutrient releasing. However, peroxide reacts with water rapidly and the excess released oxygen was also wasted by the demands of the microbes. For above reason, the aerobic condition in the overlying water did not show an immediate increase after the alteration but slowly it increased (Nykanen et al. 2012). Nevertheless, in consideration of avoiding the waste of oxygen, nitrogen nutrient release would be constrained if the oxygen-releasing material were able to release oxygen for several months or years steadily, so that water and sediment restoration could be more effective.

This research was to test a method for increasing the oxygen level of sediments treated by calcium peroxide $\left(\mathrm{CaO}_{2}\right)$ as a compound for the slow release of oxygen and to stimulate the aerobic microbial population to degrade organic matter in the sediment. The objectives of this research were to (1) investigate the effect of calcium peroxide treatment (inside sediment) on the physical parameter flux (dissolved oxygen (DO), pH, oxidation reduction potential (ORP)) in different levels of water column (2) measure vertical distribution of $\mathrm{N}$ nutrients (N-NH${ }_{4}{ }^{+}, \mathrm{N}-\mathrm{NO}_{3}{ }^{-}$, and $\mathrm{N}-\mathrm{NO}_{2}{ }^{-}$) and Chl- $a$ in the system, and (3) identify the bacterium classes growth in the sediment.

\section{Methods}

\section{Sample collection and study}

Marine sediment and water samples were collected near a marine college in the city of Tongyeong $\left(34^{\circ} 50^{\prime} 28.5^{\prime \prime} \mathrm{N}\right.$ $\left.128^{\circ} 28^{\prime} 16.4^{\prime \prime} \mathrm{E}\right)$, in the southeast coast of Korea, in March 2016. The sampling site was characterized by odorous sediment and water due to multiple sources such as waste dumping thru a pipeline and fishing activities especially by aquaculture activities. Sediment sample were collected from $10 \mathrm{~m}$ below of water level using a boat provided by a university thru a stainless steel grab sampler. The sampler was cleaned by deionized water before use to avoid unnecessary contamination. The sediment was immediately sealed in cleaned polythene bags and placed in covered buckets. Sea water was collected from the same site. A sufficient amount of sea water was collected as sample from the water column at a depth of $0.5 \mathrm{~m}$ by a water sampler. To make sure of the homogeneity, sampling was restricted in a relatively small area. The sediment and water samples were transferred immediately in the laboratory to quantify the physiochemical characteristics (Table 1). For quantification of physiochemical parameters of the sediment, the upper sediment in a depth of $10 \mathrm{~mm}$ was separated for disposal, large plant debris were removed, and then the sediment was homogenized. The collected samples were stored in a dark cold room at $4{ }^{\circ} \mathrm{C}$ prior to use.

\section{Column packing and incubations}

Two sets (one for control and one for agent) of transparent columns were set up for this study. Each set consisted of five columns $(20 \mathrm{~cm}$ in diameter $\times 110 \mathrm{~cm}$ in height) packed with sediment and overlying water. One set was filled with about 300 -g sediment mixed with $1 \%$ $(v / v)$ of $\mathrm{CaO}_{2}$ (treated as agent D), while the other set was filled by the same quantity of natural sediment (treated as control). Sediment samples were injected into the column to a height of $20 \mathrm{~cm}$ from the bottom and filled with filtered sea water slowly by the height of $40 \mathrm{~cm}$. All columns were then incubated at a room temperature of $22 \pm 1{ }^{\circ} \mathrm{C}$ for $1,2,3,4$, and 5 weeks. In every week, one column from each set was opened to analyze the overlying water. A schematic diagram of the experimental setup is shown in Fig. 1. The overlying water columns were marked as top, middle, and bottom from the surface of the water by the distance of 13, 26, and $40 \mathrm{~cm}$, respectively. During the experimental period, dissolved oxygen (DO; YSI 550 A YSI Inc., USA, SENSOREX S200C), pH, and oxidation reduction potential (ORP; Orion ${ }^{\text {тм }}$ ORP Electrode) of overlying water were measured at 1 week interval from the top, middle,

Table 1 Physiochemical characteristics of the sediment and water

\begin{tabular}{lll}
\hline Parameters & Sediment & Water \\
\hline $\mathrm{pH}$ & 7.9 & 7.81 \\
$\mathrm{DO}(\mathrm{mg} / \mathrm{L})$ & - & 5.87 \\
$\mathrm{ORP}(\mathrm{mV})$ & -88 & 412 \\
$\mathrm{~N}-\mathrm{NO}_{2}^{-}(\mathrm{mg} / \mathrm{L})$ & 0.07 & 0.008 \\
$\mathrm{~N}^{-\mathrm{NO}_{3}}{ }^{-}(\mathrm{mg} / \mathrm{L})$ & 0.41 & 0.13 \\
$\mathrm{~N}^{-N_{4}}{ }^{+}(\mathrm{mg} / \mathrm{L})$ & 0.51 & 0.20 \\
$\mathrm{Chl}-a(\mu \mathrm{g} / \mathrm{L})$ & - & 0.10 \\
$\mathrm{COD}(\mathrm{mg} / \mathrm{g})$ & 31.79 & - \\
AVS $(\mathrm{mg} / \mathrm{g})$ & 0.12 & - \\
Moisture $(\%)$ & 62 & - \\
\hline
\end{tabular}




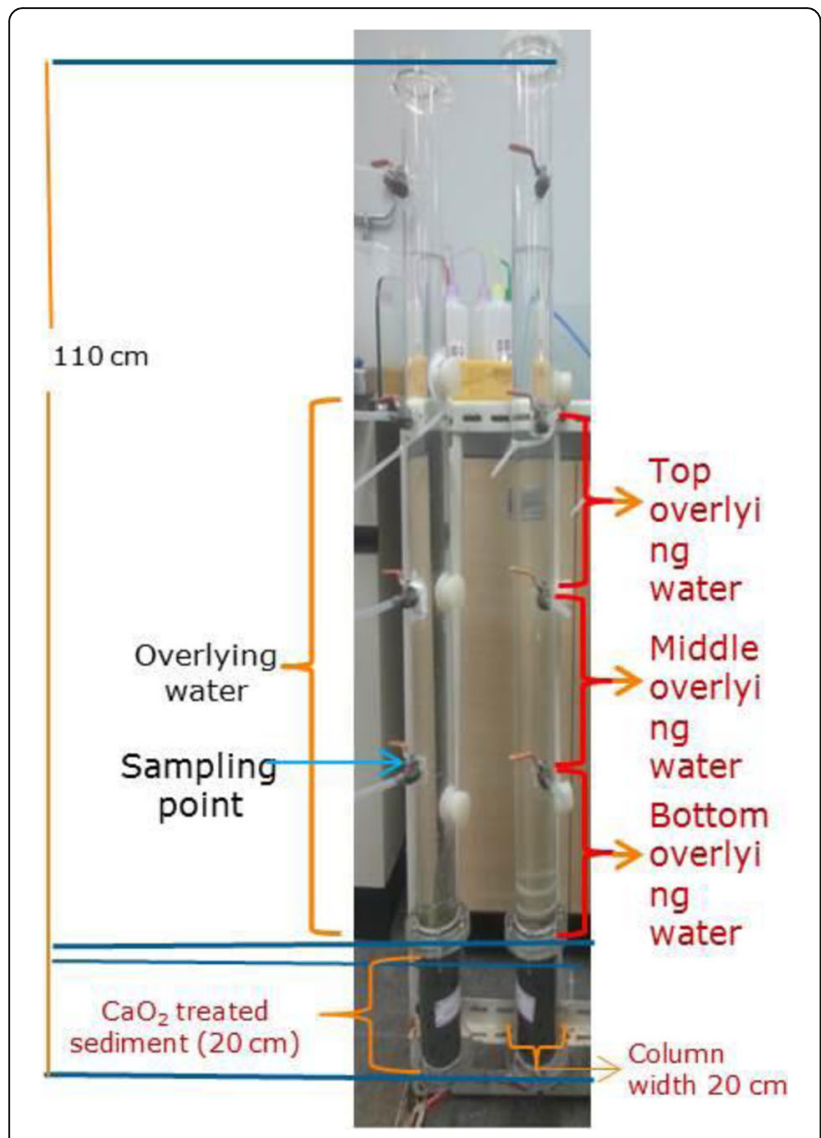

Fig. 1 Setup illustration of columns

and bottom of the water column till 5 weeks. Water samples were collected thru the sampling point of the column and three different layers for analysis of $\mathrm{N}\left(\mathrm{N}-\mathrm{NH}_{4}{ }^{+}, \mathrm{N}_{-} \mathrm{NO}_{3}{ }^{-}\right.$, and $\left.\mathrm{N}-\mathrm{NO}_{2}{ }^{-}\right)$and Chl- $a$.

\section{Chemical analysis}

The chemical oxygen demand (COD) was analyzed by the reducing agent of potassium permanganate followed by the iodometric titration method, and the acid-volatile sulfide (AVS) was measured by the sulfide detection tube (Detector tube No. 201H; GASTEC, Kanagawa, Japan) as follows: $2 \mathrm{~g}$ of a sample were mixed with 2-mL concentrated sulfuric acid, which was continuously pumped into the tube, until the color of the tube changed. Water samples were filtered through a glass microfiber filter (GF/C, Whatman, Brentford, UK). The concentration of nitrogen ammonium $\left(\mathrm{N}-\mathrm{NH}_{4}{ }^{+}\right)$was determined by indophenol blue method, and nitrate $\left(\mathrm{N}-\mathrm{NO}_{3}{ }^{-}\right)$and nitrite $\left(\mathrm{N}-\mathrm{NO}_{2}{ }^{-}\right)$concentration was measured by $\mathrm{N}$-(1-naphthyl)-ethylenediamine adsorption spectrophotometry and $\mathrm{Cd}-\mathrm{Cu}$ reduction $\mathrm{N}$-(1-naphthyl)ethylenediamine adsorption spectrophotometry, respectively. All spectroscopic analyses were done by UV Mini1240 spectrophotometer (Shimadzu Corporation, Kyoto, Japan). Chlorophyll- $a$ have been measured as extractable chl- $a$ from water samples and analyzed by the spectrofluoro-meter (Shimadzu Mod., RF 1501) methods described in Antonietta et al. (2009). Analytical grade chemicals were used in all experiments. For all samples, sediment and overlying water were analyzed in triplicates and all data are reported as the average of the three subsamples.

\section{Microbial community analysis}

The microbial community was analyzed via FastDNA SPIN Kit for Soil (MP Biomedicals, Santa Ana, CA, USA) following the methods described by Cho et al. (2014). First, 16S rDNA out of the extracted DNA samples were identified using primers $27 \mathrm{f}$ and $1492 \mathrm{r}$. The second touch-down polymerase chain reaction (PCR) was run through the $16 \mathrm{~S}$ rDNA V3 region and reamplified with primer GC-341F equipped with 40-bp GC-clamps (Bioneer Inc., Daejeon, Korea). In PCR, a sample was heated at $95{ }^{\circ} \mathrm{C}$ for $5 \mathrm{~min}$ and was denatured for $30 \mathrm{~s}$. Then, it was annealed starting at $65^{\circ} \mathrm{C}$ decreasing by $0.5{ }^{\circ} \mathrm{C}$ per cycle, 15 more cycles at $55^{\circ} \mathrm{C}$, and $45 \mathrm{~s}$ of elongation at $72{ }^{\circ} \mathrm{C}$ within $10 \mathrm{~min}$. The products of PCR were identified in $1 \%$ of agarose gel. DNA fragments were cut from bands on the denaturing gradient gel and were washed with highly purified distilled water. After being added with TE buffer ( $25 \mathrm{uL})$, the DNA samples were centrifuged at $13,500 \mathrm{~g}$ for $1 \mathrm{~min}$. The collection was frozen $\left(-70{ }^{\circ} \mathrm{C}\right)$ and thawed $\left(45^{\circ} \mathrm{C}\right)$ three times for $15 \mathrm{~min}$ each. After centrifugation, the supernatant was collected for further analysis. The finalized collections were amplified again for an NCBI BLAST (Basic Local Alignment Search Tool) search designated for the most probable phlemonic similarity.

\section{Statistical analysis}

Data were analyzed using SPSS 18.0.1 statistical packages. The relationships between different parameters were tested statistically using general correlation coefficient (Pearson) procedures in SPSS.

\section{Results and discussion}

Changes of dissolve oxygen, $\mathrm{pH}$, and oxidation reduction potential in overlying water

\section{Dissolve oxygen}

Dissolve oxygen (DO) of overlying water have been changed with level distance and time in both columns. Oxygen concentrations were affected by the addition of $\mathrm{CaO}_{2}$ but the effect depended on the depth variation. DO concentrations in the control column remain relatively constant until 2 weeks of the experimental period, and then, it began to decrease (Fig. 2). While in the treatment column, a gradual decline was observed during the first week and then increased over the course of the experiment. During these periods, oxygen concentration of overlying water did not differ between the 


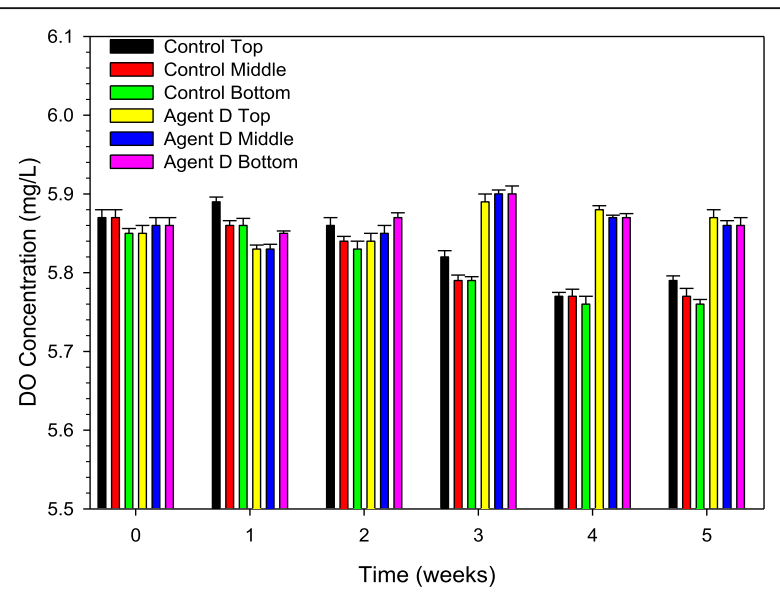

Fig. 2 Changes of dissolve oxygen (DO) of the overlying water in the control and $\mathrm{CaO}_{2}$ (agent D)-treated column

control and treatment columns. Moreover, bottom water oxygen concentrations were higher by $0.15 \mathrm{mg} / \mathrm{L}$ in the treatment column than those in the control column at the end of the study and the acquired data set of the study were statistically significant $(p<0.05)$. It depicts that untreated sediment promoted the depletion of DO in the overlying water, but $\mathrm{CaO}_{2}$-treated sediment improved DO which was sustained until the closing of the experiment. The DO concentration in the overlying water of the treatment column was higher than that of the control column at 3 weeks. The $\mathrm{CaO}_{2}$ could support to raise the number of bacterial density such as heterotrophic aerobic bacteria in the sediment which have fluctuated during the test (Nykanen et al. 2012). This indicates that the increase in aerobic bacterial density increased biodegradation process which led to a high amount of dissolved $\mathrm{CO}_{2}$ and consumption of DO. Besides, the competition for $\mathrm{O}_{2}$ between nitrifiers and heterotrophic bacteria intensifies in this condition. Although oxygen consumption apparently rose as a result of the stimulated bacterial growth, the oxygen concentration of the overlying water for the treatment column began to increase after 2 weeks and finally stayed at higher levels than that for the control. According to Cooke et al. (2005), if all oxygen starts escaping the site of release (overlying water), $\mathrm{CaO}_{2}$-treated sediment will still benefit the environment by improving the oxygen concentration of the water. But in the case of the control, consumption of DO in the sediment and water by ammonia oxidation increased over the course of the experiment. Because, heterotrophic bacteria involved stronger ammonifying and denitrifying processes which resulted in more ammonia concentration in the sediment, which further moved into the water and kept the high ammonia concentration (Zhang et al. 2007) and
DO may have been consumed by this oxidation of ammonia (Asaoka et al. 2009).

$p H$

The $\mathrm{pH}$ of the water column rise very rapidly (Fig. 3) in the treatment column due to the formation of $\mathrm{Ca}(\mathrm{OH})_{2}$ in a reaction between $\mathrm{CaO}_{2}$ and water (Solvay, 2012). The $\mathrm{pH}$ in overlying water was a predominant factor, as it affected sorption-adsorption, precipitation-solubilization, and oxidation-reduction reactions through its control over the concentration of available iron, aluminum, and calcium, thus directly or indirectly changing the aquatic, biological and chemical reactions as has been suggested by Jin et al. (2006). Wang et al. (2005) suggested that a change of $\mathrm{pH}$ in overlying water resulting from oxygen supply intensities represents one of the most important ways for nutrient release from sediments. Decrease of COD and AVS in the treatment column was observed over incubation periods with the addition of $\mathrm{CaO}_{2}$, which could be attributed to sulfate-reducing bacteria (SRB), and anaerobic biological activity faces growth inhibition. Chemical oxidation of sulfide and biotic inhibition of SRB are two major mechanisms by which slow oxygenreleasing solids such as calcium peroxide $\left(\mathrm{CaO}_{2}\right)$ may be able to decrease sulfide concentration as also revealed by Chang et al. (2007). Slow release of oxygen hydrolyzes through the addition of water to calcium hydroxide $\mathrm{Ca}(\mathrm{OH})_{2}$ and hydrogen peroxide $\left(\mathrm{H}_{2} \mathrm{O}_{2}\right)$ (Hanh et al. 2005) as shown in the Eqs. (1) and (2).

$$
\begin{aligned}
& \mathrm{CaO}_{2}+2 \mathrm{H}_{2} \mathrm{O} \rightarrow \mathrm{H}_{2} \mathrm{O}_{2}+\mathrm{Ca}(\mathrm{OH})_{2} \\
& 2 \mathrm{H}_{2} \mathrm{O}_{2} \leftrightarrow 2 \mathrm{H}_{2} \mathrm{O}+\mathrm{O}_{2} \uparrow
\end{aligned}
$$

An acidic condition and abundant presence of sulfatereducing bacteria are known to produce more $\mathrm{H} 2 \mathrm{~S}$ which are observed in the control column but $\mathrm{CaO}_{2}$, an excellent oxygen producer, seemed to suppress this anaerobic action because it continuously inputs molecular oxygen (Eq. (3)) in the presence of water which enhanced bacterial efficiency through the maximization of the aerobic bacterial production (Bissett et al. 2007).

$$
2 \mathrm{CaO}_{2}+2 \mathrm{H}_{2} \mathrm{O} \rightarrow \mathrm{O}_{2} \uparrow+2 \mathrm{Ca}(\mathrm{OH})_{2}
$$

In addition, hydrogen sulfide reacting with $\mathrm{Ca}(\mathrm{OH})_{2}$ (active in $\mathrm{pH}$ 6.5-7.5) can be easily transformed to calcium sulfate (Eq. (4)) in the alkaline environment (pH higher than 8.5), thus lowering AVS matter in sediment.

$$
\mathrm{Ca}(\mathrm{OH})_{2}+\mathrm{H}_{2} \mathrm{~S}+2 \mathrm{O}_{2} \rightarrow \mathrm{CaSO}_{4}+2 \mathrm{H}_{2} \mathrm{O}
$$

$\mathrm{pH}$ increases in the sediment and overlying water of the treatment column which is caused by the hydrolysis 


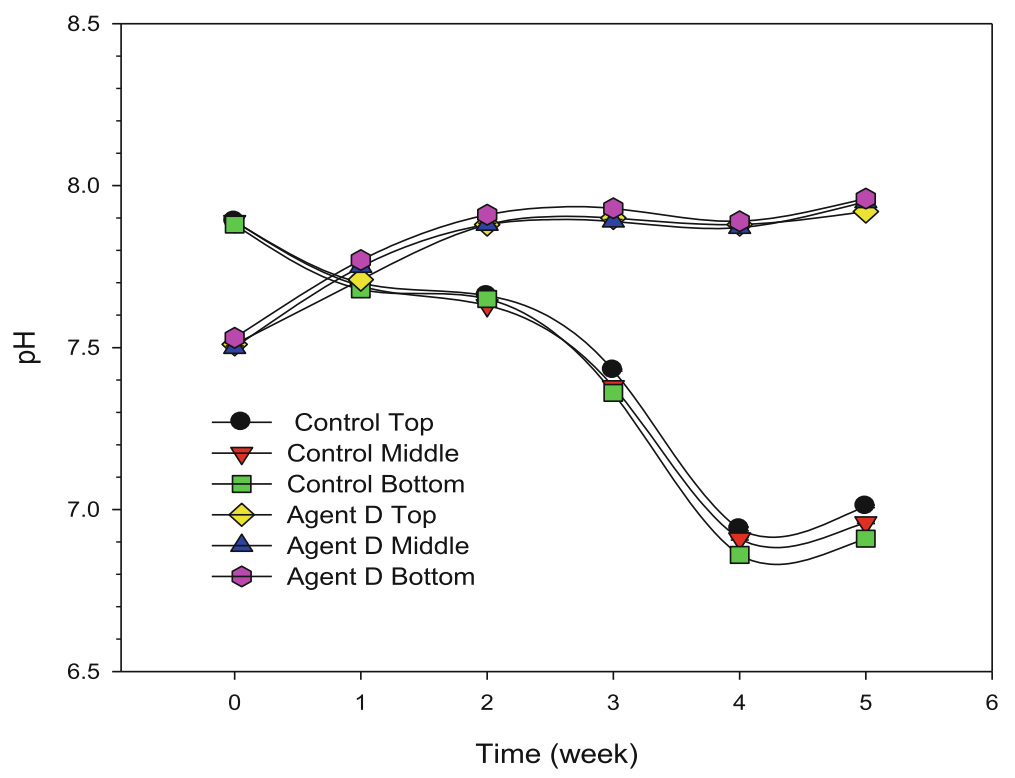

Fig. 3 Changes of $\mathrm{pH}$ of the overlying water in the control and $\mathrm{CaO}_{2}$ (agent D)-treated column for 35 days

of calcium. Oxides are converted to hydroxides over time (as oxygen is released), and even larger $\mathrm{pH}$ differences are observed because $\mathrm{Ca}(\mathrm{OH})_{2}$ helps in increasing the $\mathrm{pH}$. But the bacterial density were not affected negatively and stayed elevated (Nykanen et al. 2012). Hence, the advantages of $\mathrm{CaO}_{2}$ are low disproportionation and long-lasting effectiveness for in situ remediation (Liu et al., 2016a, b).

\section{Oxidation reduction potential}

Oxidation reduction potential (ORP) concentrations in the overlying water of the control column were found suppressed compared to those of the $\mathrm{CaO}_{2}$-treated column (Fig. 4). Until week 3, ORP change was not distinguishable between the control and agent-treated columns. The ORP value after 3 weeks has showed isolation in Fig. 4, which indicates the difference of inside situation. The promotion of ORP was found by $1.5 \%$ higher in the agent-treated overlying water than that in the control overlying water. In natural organically enriched sediment column (control), the decomposition of organic molecule restricts oxygen supply, so ORP drops, because reduced substances want to dump electrons into the ORP probe. In the control column, lower ORP may mean the higher growth of the sulfatereducing bacteria. These can produce enough sulfides and maintain an oxygen-deficient condition (Zhang et al. 2015). Li et al. (2009) also found that the ORP value was strongly affected by the concentration of the reductive sulfur compounds. But with the addition of an agent, it rises. In the agent-treated column, ORP increased by $2 \%$ from the beginning of the study until the closing time (5 weeks). The COD value decreased with increasing time on the treatment column indicating the existence of active microbial consortium. Since the microbes were present in the sediment, the decreasing rate of the organic matter was greatly improved because microbes absorbed organic pollutant as the energy source. Microbes extract energy via energy-yielding biochemical reactions mediated by the microbial oxidoreductase enzymes to cleave chemical bonds and to assist the transfer of electrons from a reduced organic substrate (donor) to another chemical compound (acceptor) (Karigar and Rao 2011). During such oxidation-reduction reactions, the pollutants are finally oxidized to harmless compounds. The growth of heterotrophic aerobic bacteria in sediment was enhanced after increasing the oxygen level

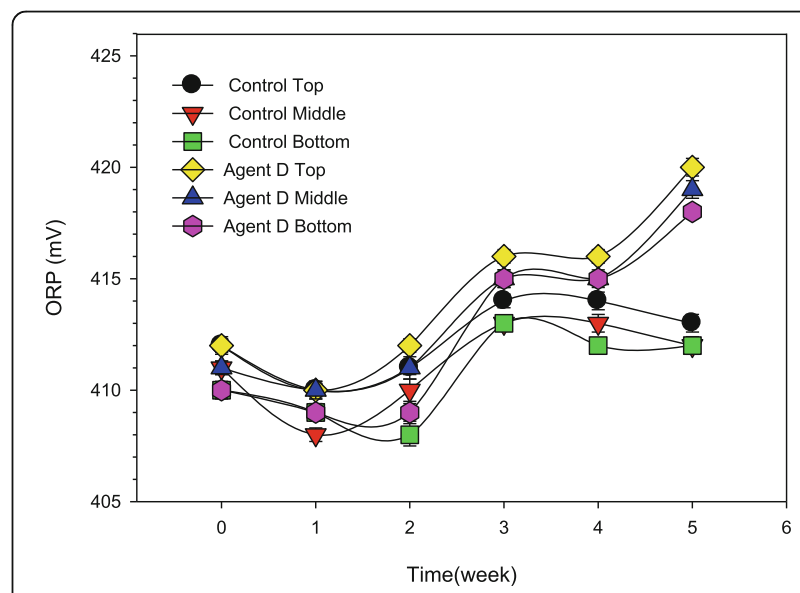

Fig. 4 Changes of ORP of the overlying water in the control and $\mathrm{CaO}_{2}$ (agent D)-treated column for 35 days 
in water and sediment by adding $\mathrm{CaO}_{2}$, which has been used to enhance bioremediation of contaminated sediment by releasing oxygen and then improving its reducing condition (Nykanen et al. 2012), so the high performance of $\mathrm{CaO}_{2}$ might be explained as a continuous input of molecular oxygen by oxygen-releasing solid oxides which helps internal microorganisms enhance their efficiency.

\section{Changes of $\mathrm{N}-\mathrm{NH}_{4}{ }^{+}, \mathrm{N}-\mathrm{NO}_{3}{ }^{-}$and $\mathrm{N}-\mathrm{NO}_{2}{ }^{-}$concentrations in overlying water}

Figure 5 shows $\mathrm{N}_{-} \mathrm{NH}_{4}{ }^{+}$distributions in the studied column. The concentration of $\mathrm{N}-\mathrm{NH}_{4}{ }^{+}$in overlying water of the control column was increased with time. The highest concentration was observed in the bottom part of the water level among the three layers. The increase of ${\mathrm{N}-\mathrm{NH}_{4}}^{+}$was found from the initial week, and the slow gradual increase was kept to the end of the experiment. Along the column, $\mathrm{N}-\mathrm{NH}_{4}{ }^{+}$concentrations in the top and middle water was lower than the bottom, but no statistically significant difference was observed between these three layers. Besides, the concentrations of $\mathrm{N}^{-\mathrm{NH}_{4}}{ }^{+}$ in the agent-treated column were observed to be lower than those in the control for all three levels of water column. The result is implying that notable ammonia accumulation in the untreated sediment (control) and its significant release to the overlying water. The applied agent helps to suppress $\mathrm{N}-\mathrm{NH}_{4}{ }^{+}$by $63 \%$ compared with natural sediment (control). However, $\mathrm{N}-\mathrm{NH}_{4}{ }^{+}$concentration of pore water of sediment also showed to be high in the control.

The concentration of $\mathrm{N}_{-} \mathrm{NO}_{3}{ }^{-}$in the overlying sea water of the treatment column varied from 0.10 to $0.13 \mathrm{mg} / \mathrm{L}$, regardless of the incubation period (5 weeks), while its concentration of the corresponding control column was in the range of 0.12 to $0.08 \mathrm{mg} / \mathrm{L} \mathrm{N}^{-N}{ }_{3}{ }^{-}$for

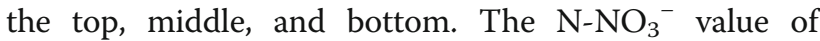
agent-treated column water is shown to be higher by $7 \%$ than that of the control column water concentration indicating that there was a release of nitrate from the natural sediment than agent-treated sediment into the overlying water (Fig. 6).

$\mathrm{N}-\mathrm{NO}_{2}{ }^{-}$concentration in the overlying water for control and treatment were inconsistent with time during the test (Fig. 7). But it is notable that among the water layers, the top portion of the agent-treated column was about

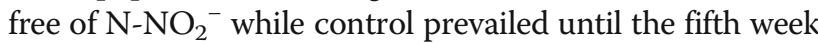
of the experiment. Due to the input of oxygen and nitrogen through bioremediation of organic matter inside the sediment which ought to enter into the water column, the result could be an increased concentration of $\mathrm{N}_{-} \mathrm{NH}_{4}{ }^{+}$and $\mathrm{N}-\mathrm{NO}_{3}{ }^{-}$and a decrease of $\mathrm{N}-\mathrm{NO}_{2}{ }^{-}$, which became negligible (Wu et al. 2008). Gomez et al. (1999) research supports that the adsorption and release of $\mathrm{N}$ nutrients from sediments depends on various factors such as $\mathrm{pH}$, ORP, and temperature. The studied results of the present experiment are attributed to the experimental condition which was favorable to $\mathrm{N}$ circulations and transformations, resulting in a large flux of $\mathrm{N}^{-\mathrm{NH}_{4}}{ }^{+}$and $\mathrm{N}-\mathrm{NO}_{3}{ }^{-}$ with negligible amount of $\mathrm{N}^{-\mathrm{NO}_{2}}{ }^{-}$.

\section{Chlorophyll-a}

Chlorophyll- $a$ concentrations measured in the overlying water were high and analogous at the anoxic control and agent-treated column at opening (Fig. 8). At week 1, maximum fall (40\%) of chlorophyll- $a$ concentrations was observed in the overlying water of the control column.

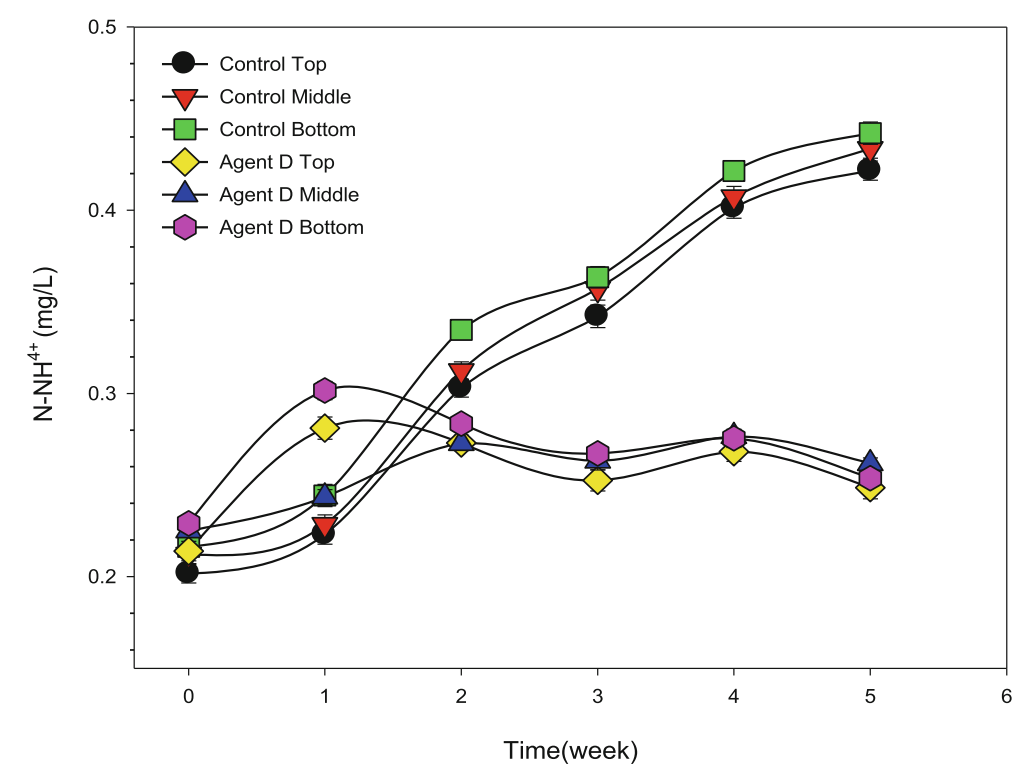

Fig. 5 Changes of ${\mathrm{N}-\mathrm{NH}_{4}}^{+}$in the overlying water in the control and $\mathrm{CaO}_{2}$ (agent D)-treated column 


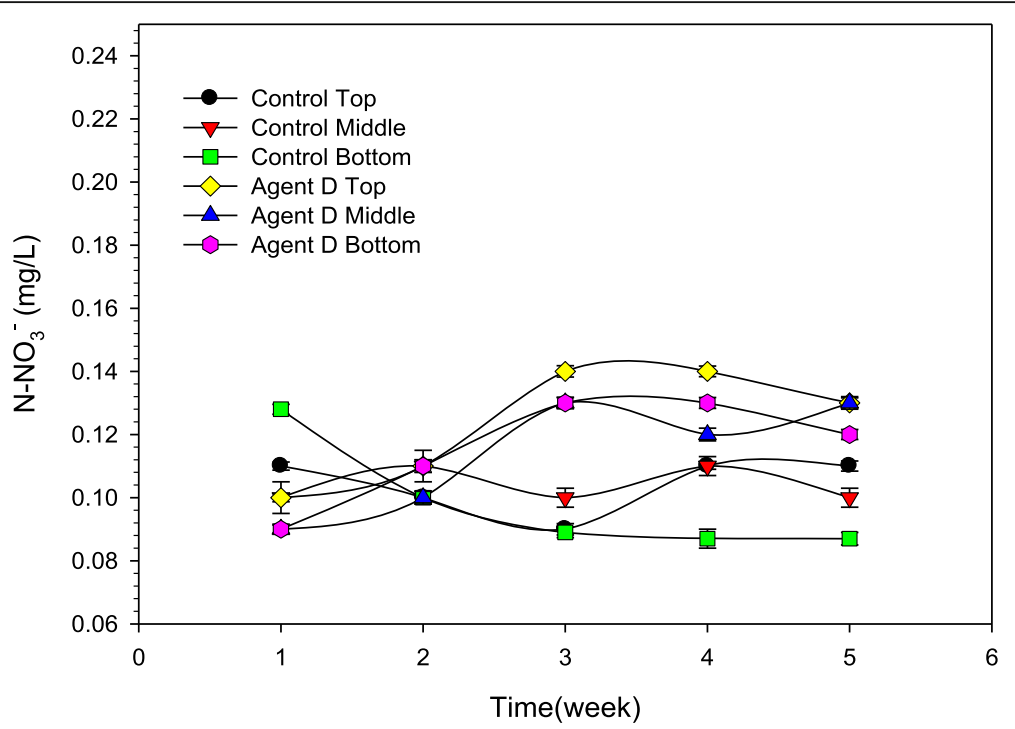

Fig. 6 Changes of $\mathrm{N}^{-N_{3}}{ }_{3}^{-}$in the overlying water in the control and $\mathrm{CaO}_{2}$ (agent D)-treated column

Chlorophyll- $a$ concentrations, after week 2 , in the agenttreated column was found unchanged by $0.07 \mu \mathrm{g} / \mathrm{L}$ over the period, at the same time in the overlying water of the control column exposed an elevation phenomenon that is ended by $0.09 \mu \mathrm{g} / \mathrm{L}$. Furthermore, $\mathrm{CaO}_{2}$ addition and not addition resulted in a decrease in chlorophyll- $a$, presumably through the control of internal nutrient loading from sediment-water interface. In overlying water of the treatment column, DO, ORP, and $\mathrm{pH}$ were observed to be higher than in the control part. Oxygen release from calcium peroxide could facilitate nitrifying and suppress denitrifying activation process by its bacterial (zooplankton) activity. Besides that, in the overlying water of control column, higher concentration of $\mathrm{N}^{-\mathrm{NH}_{4}}{ }^{+}$is indicating the higher denitrification inside the sediment. These outcomes also reflecting the excessive photosynthesis activity by phytoplankton biomass could be a worthy explanation of higher chlorophyll- $a$ concentrations in the overlying water of the control column (Antonietta et al. 2009).

\section{Coefficients of correlation between environmental parameters and nutrients}

Pearson correlation between environmental parameters and nitrogen compounds at the sediment-water interface of the control during the study period is shown in Table 2 .

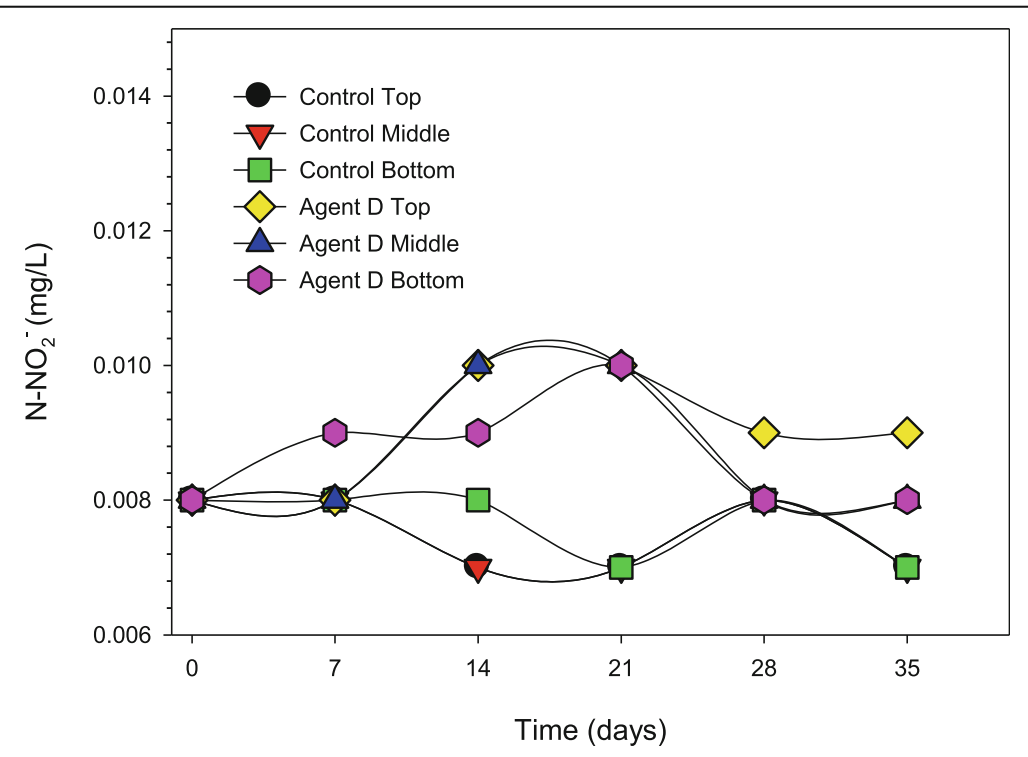

Fig. 7 Changes of ${\mathrm{N}-\mathrm{NO}_{2}}^{-}$in the overlying water in the control and $\mathrm{CaO}_{2}$ (agent D)-treated column 


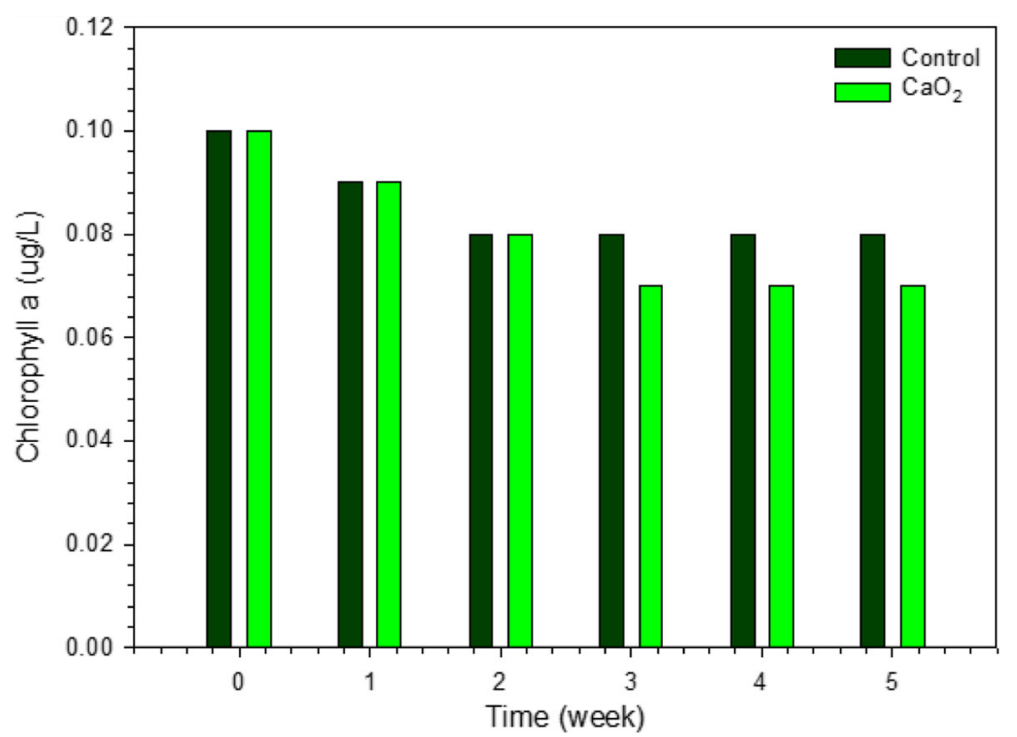

Fig. 8 Changes of Chlorophyll-a in the overlying water in the control and $\mathrm{CaO}_{2}$ (agent D)-treated column

DO showed correlation $(p<0.05)$ with $\mathrm{pH}$ (positive), $\mathrm{N}-\mathrm{NO}_{3}{ }^{-}$(positive), and $\mathrm{N}-\mathrm{NH}_{4}{ }^{+}$(negative). Nitrogen species showed significant correlations among themselves. However, $\mathrm{DO}, \mathrm{pH}$, and $\mathrm{N}-\mathrm{NO}_{3}^{-}$all showed significant negative correlation with $\mathrm{N}-\mathrm{NH}_{4}{ }^{+}$.

\section{Effect of $\mathrm{pH}$ and DO on ammonia and nitrate dynamics in overlying water}

Previous researches have revealed that nitrification has a significant effect on oxygen consumption in various aquatic systems (Hsiao et al. 2014). Our results showed that $\mathrm{N}-\mathrm{NO}_{3}{ }^{-}$was positively correlated with DO. During the early period of the experiment, DO showed an increase trend in control, and as a consequence, the vitality of nitrifying microorganisms was stored and the concentration of nitrate increased to a certain extent. Once started, nitrification costed additional oxygen and might result in an anoxic condition. This would be an important reason for the decreasing trend of both DO and $\mathrm{N}_{-} \mathrm{NO}_{3}{ }^{-}$after 2 weeks of the experiment. Without supplement of oxygen, DO levels were limited in control; thus, nitrification was less intensive than that in the $\mathrm{CaO}_{2}$-treated column because nitrification cannot proceed under low DO condition. On treatment column, nitrification remained in the first stage until week 3 , indicating the periodic burst of oxygen consumption associated with nitrification and organic matter degradation process which constituted a significant impact

Table 2 The correlations between environmental parameters and nitrogen compounds at the sediment-water interface of the control

\begin{tabular}{|c|c|c|c|c|c|}
\hline & & $\mathrm{DO}$ & $\mathrm{pH}$ & $\mathrm{N}-\mathrm{NO}_{3}^{-}$ & $\mathrm{N}-\mathrm{NH}_{4}{ }^{+}$ \\
\hline \multirow[t]{3}{*}{$\overline{\mathrm{DO}}$} & Pearson correlation & 1 & $.956^{*}$ & $.933^{*}$ & $-.958^{*}$ \\
\hline & Significance (two-tailed) & - & .000 & .000 & .000 \\
\hline & $N$ & 18 & 18 & 18 & 18 \\
\hline \multirow[t]{3}{*}{$\mathrm{pH}$} & Pearson correlation & $.956^{*}$ & 1 & $.819^{*}$ & $-.939^{*}$ \\
\hline & Significance (two-tailed) & .000 & - & .000 & .000 \\
\hline & $N$ & 18 & 18 & 18 & 18 \\
\hline \multirow[t]{3}{*}{$\mathrm{N}-\mathrm{NO}_{3}^{-}$} & Pearson correlation & $.933^{*}$ & $.819^{*}$ & 1 & $-.938^{*}$ \\
\hline & Significance (two-tailed) & .000 & .000 & - & .000 \\
\hline & $N$ & 18 & 18 & 18 & 18 \\
\hline \multirow[t]{3}{*}{$\mathrm{N}-\mathrm{NH}_{4}{ }^{+}$} & Pearson correlation & $-.958^{*}$ & $-.939^{*}$ & $-.938^{*}$ & 1 \\
\hline & Significance (two-tailed) & .000 & .000 & .000 & - \\
\hline & $N$ & 18 & 18 & 18 & 18 \\
\hline
\end{tabular}

*Correlation is significant at the 0.01 level (two-tailed) 
factor to oxygen depletion. After week $3, \mathrm{~N}-\mathrm{NO}_{3}{ }^{-}$began to increase in treatment, explaining the simultaneous increase of $\mathrm{DO}$ by $\mathrm{CaO}_{2}$ but finally, some of the resulting nitrate being lost from the system indicates the denitrification process. Denitrification is the main process for nitrate attenuation (Jing et al. 2013). pH is another most important factor of nutrient release. Comparably, under high DO condition, the $\mathrm{N}-\mathrm{NH}_{4}{ }^{+}$concentration were apparently higher at low $\mathrm{pH}$ than that at high $\mathrm{pH}$. This phenomenon could be due to the sufficient $\mathrm{H}^{+}$under acid conditions $(\mathrm{pH}<7)$ that would inhibit the activity of nitrifying bacteria at the water-sediment interface, resulting in slower rate of conversion from ammonium to nitrate. Thereafter, ammonium accumulated abundantly in the surface sediment and is further released, leading to higher ammonium concentration in overlying water. Enough molecular oxygen can also inhibit the activity of denitrifying enzymes, especially that of nitrite reductase enzyme (Jing et al. 2013). Concurrently, in overlying water, denitrification rates tended to be higher in regions of low pH low oxygen concentration (Zhang et al. 2014). But in treatment column, under an aerobic and alkaline condition, abundant $\mathrm{OH}^{-}$was present, which reacts with the ammonium released from the sediment into overlying water. Hence, the ammonium would be converted directly to $\mathrm{N}_{-} \mathrm{NO}_{3}{ }^{-}$and escaped from the water body, which was reflected in the lower ammonium concentration in overlying water.

\section{DGGE band analysis and community's phylogenetic affiliation}

Microbial consortia of sediment are very important for bioremediation of pollutants. The biodegradation of oil hydrocarbons is a process well established in nature and known to man for a long time (Sohngen 1913). Intensity and rate of this degradation obviously depended upon the inoculum or abundant microbial community. During the 5 weeks of experimentation, significant changes were observed in all columns. Color had changed from transparent to black that was substantial with natural sediment (control) than oxygen-supplier agent sediment. It is attributed to the growth of microbial community in the agent-treated sediment which was smoothed than control. Head et al. (2006) has been postulating that the biodegradation of hydrocarbons is conducted by numerous genera of bacteria, fungi, and algae. The DGGE was performed for phylogenetic analysis of bacterial population which involved the pollutant degradation process. Resulting DGGE gels (Fig. 9) contained samples taken from $\mathrm{CaO}_{2}$-mixed sediment and control sediment. Selections of distinct bands are marked in Fig. 9, and the corresponding phylogenetic affiliation could be seen in Table 3. In general, there was a higher diversity of band patterns registered in samples containing $\mathrm{CaO}_{2}$. This

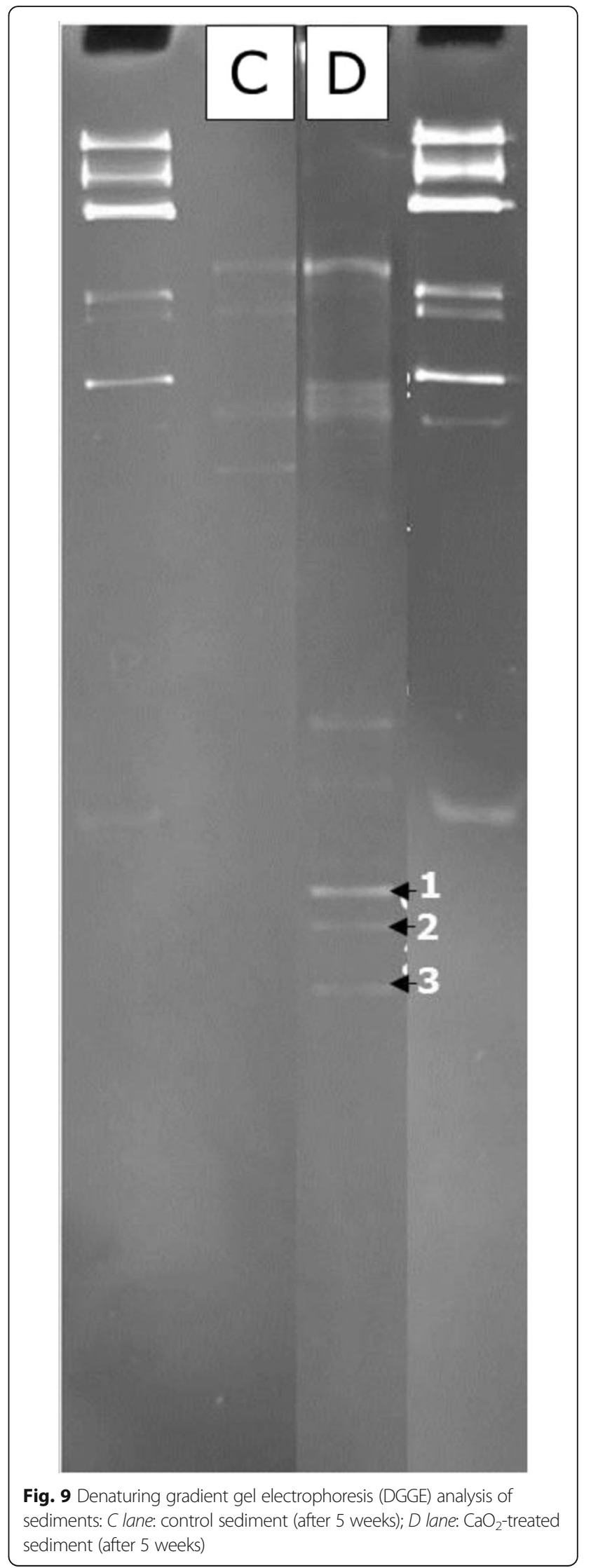


Table 3 Base sequence of 165 rDNA revealed from DGGE bands

\begin{tabular}{lllll}
\hline DGGE band & & NCBI accession no. & Description & Identity (\%) \\
\hline 1 & & FM211085.1 & Uncultured marine bacterium & $98 \%$ \\
2 & Not Assembly & - & - \\
3 & LN878307.1 & Uncultured Actibacter sp. & $83 \%$ \\
& 341F & NR_043099.1 & Salegentibacter flavus strain & $94 \%$ \\
\hline
\end{tabular}

DGGE denaturing gradient gel electrophoresis, NCBI National Center for Biotechnology Information

was found particularly in the upper part of the sediment. Several significant bands marked with 1,2 , and 3 were detected in the parts of the DGGE gels. These bands mostly belong to a cluster of species closely related to the genus Actibacter and Salegentibacter group. Both phylogenetic groups comprise common members of the natural marine microflora.

The control and agent-treated sediment columns have not showed bacterial identity at beginning of the experiment. Although this form was unchanged for control sediment, agent-treated sediment showed bacterial identity after 5 weeks of experiment. It could be associated that the agent has an effect to the growth bacterial species.

\section{Conclusion}

The water-sediment system is usually disturbed by biodegradation process of organic and inorganic matter inside sediment. This study observed the system parameters changes during 5 weeks of experiment especially parameters of overlying water. Most of the study focuses on sediment remediation; although, the parameter changes in the overlying water could massively affect the ecology. Sediment and water exposed significant and visual changes by the internal parameter changes due to application of calcium peroxide. Parameters of overlying water were found greatly altered in calcium-peroxidetreated sediment column than in non-treated sediment column. These could be due to chemical composition changes in sediment and nutrient dynamics from sediment to water layer. The DO in the control column water was found unchanged until 2 weeks when it was 1 week for agent-treated column. After the pointed time, DO was changed by decline in control column overlying water and was inclined in treatment column overlying water until 5 weeks. By way of $\mathrm{pH}$, result has pointed that the agent treatment in sediment suppresses excess nutrient loading in overlying water than what occurred in the control for a long lasting period. The ORP at the beginning of 3 weeks was not distinguishable between the control and treatment columns' overlying water over the 5 weeks of study. ORP in overlying water of treatment column were found to be increased by $2 \%$ from the start to the end of the study. Agent showed 1.5\% efficacy than natural condition by changes in ORP of overlying water. Oxygen-releasing agent calcium peroxide was affecting nutrient dynamics of $\mathrm{N}^{-\mathrm{NH}_{4}}{ }^{+}$suppression by $63 \%$ than the overlying water of the control column when it was reverse by $7 \%$ for $\mathrm{N}_{-} \mathrm{NO}_{3}{ }^{-}$. But changes of $\mathrm{N}^{-\mathrm{NO}_{2}}{ }^{-}$were found inconsistent and negligible for the overlying water in both columns. Photosynthesis pigment chlorophyll- $a$ concentrations were found in a declining pattern for the overlying water in both columns. But this decrease was higher in the agenttreated column's overlying water by $10 \%$ in compare with control column overlying water. The microbial community residing in the sediment was found to be species closely related to the genus Actibacter and Salegentibacter group. Both phylogenetic groups of natural marine microflora were observed in treated sediment at the end of the experiment whereas no detectable species were observed in the control sediment; although, they have showed physical color change from transparent to black in the column during the study.

\section{Acknowledgments}

This research was supported by the Basic Science Research Program through the National Research Foundation of Korea (NRF) funded by the Ministry of Science ICT \& Future Planning (2017R1A2B4008720) and BK21 plus program in the Republic of Korea.

\section{Funding}

The funding was provided by the Ministry of Science ICT \& Future Planning (2017R1A2B4008720) and BK21 plus program, South Korea.

\section{Availability of data and materials}

Data and materials are available to all.

Authors' contributions

$\mathrm{MNH}$ participated in the research work and wrote down the manuscript. SHK conceived the idea and directed the research work. Both authors have read and approved the final manuscript.

\section{Ethics approval}

Not applicable.

Competing interests

The authors declare that they have no competing interests.

\section{Publisher's Note}

Springer Nature remains neutral with regard to jurisdictional claims in published maps and institutional affiliations. 


\section{Author details}

'Department of Ocean System Engineering, College of Marine Science, Gyeongsang National University, Cheondaegukchi-Gil 38, Tongyeong, Gyeongnam 650-160, Republic of Korea. ${ }^{2}$ Department of Marine Environmental Engineering, College of Marine Science, Engineering Research Institute (ERI), Gyeongsang National University, Cheondaegukchi-Gil 38, Tongyeong, Gyeongnam 650-160, Republic of Korea.

\section{Received: 18 February 2017 Accepted: 26 July 2017}

Published online: 31 August 2017

\section{References}

Antonietta, S., Raffaele, D., Monia, R., Fabio, V., Adele, F., Tommaso, S., Lucrezia, C., Marisa, F., Paolo, B., \& Alberto, B. (2009). Fluctuations of physicochemical characteristics in sediments and overlying water during an anoxic event: a case study from Lesina lagoon (SE Italy). Transit Waters Bull., 3(2), 15-32. doi: 10.1285/i1825229Xv3n2p15

Asaoka, S., Yamamoto, T., Yoshioka, I., \& Tanaka, H. (2009). Remediation of coastal marine sediments using granulated coal ash. Journal of Hazardous Materials, 172, 92-98.

Asaoka, S., Yamamoto, T., Yamamoto, H., Okamura, H., Hino, K., Nakamoto, K., \& Saito, T. (2015). Estimation of hydrogen sulfide removal efficiency with granulated coal ash applied to eutrophic marine sediment using a simplified simulation model. Marine Pollution Bulletin, 94(1-2), 55-61.

Bissett, A., Burke, C., Cook, P. L., \& Bowman, J. P. (2007). Bacterial community shifts in organically perturbed sediments. Environmental Microbiology, 9, 46-60.

Chang, Y. J., Chang, Y. T., \& Chen, H. J. (2007). A method for controlling hydrogen sulfide in water by adding solid phase oxygen. Bioresource Technology, $98,478-483$.

Cho, D., Jiang, S., \& Kwon, S. H. (2014). Chemical and biological analyses of bay sediment where magnesium oxide compounds are applied. Environmental Engineering Research, 19(1), 101-105.

Cooke, G. D., Welch, E. B., Peterson, S. A., \& Nichols, S. A. (2005). Restoration and management of lakes and reservoirs (3rd ed.). Boca Baton: Taylor and Francis

Gomez, E., Durillon, C., Rofes, G., \& Picot, B. (1999). Phosphate adsorption and release from sediments of brackish lagoons: $\mathrm{pH}, \mathrm{O}_{2}$ and loading influence. Water Research, 33, 2437-2447.

Hanh, D. N., Rajbhandari, B. K., \& Annachhatre, A. P. (2005). Bioremediation of sediments from intensive aquaculture shrimp farms by using calcium peroxide as slow oxygen release agent. Environmental Technology, 26, 581-590.

Head, I. M., Jones, D. M., \& Roling, W. F. (2006). Marine microorganisms make a meal of oil. Nature Reviews. Microbiology, 3, 173-182

Hsiao, S. S. Y., Hsu, T. C., Liu, J. W., Xie, X., Zhang, Y., Lin, J., Wang, H., Yang, J. Y. T., Hsu, S. C., Dai, M., \& Kao, S. J. (2014). Nitrification and its oxygen consumption along the turbid Chang Jiang River plume. Biogeosciences, 11, 2083-2098.

Jin, X. C., Wang, S. R., Pang, Y., \& Wu, F. C. (2006). Phosphorus fractions and the effect of $\mathrm{pH}$ on the phosphorus release of the sediments from different trophic areas in Taihu Lake, China. Environ. Pollut, 139, 288-295.

Jing, L. D., Wu, C. X., Liu, J. T., Wang, H. G., \& Ao, H. Y. (2013). The effects of dredging on nitrogen balance in sediment-water microcosms and implications to dredging projects. Ecological Engineering, 52, 167-174.

Karigar CS, Rao SS. 2011. Role of microbial enzymes in the bioremediation of pollutants. Enzyme research, 1-11: a review. Article ID 805187 http://dx.doi.org/10.4061/2011/805187

Li, W., Zhao, Q. L., \& Liu, H. (2009). Sulfide removal by simultaneous autotrophic and heterotrophic desulfurization-denitrification process. Journal of Hazardous Materials, 162, 848-853.

Liu, T., Yuan, J., Dong, W., Wu, H., \& Wang, H. (2015). Effects on inorganic nitrogen compounds release of contaminated sediment treatment with in situ calcium nitrate injection. Environmental Science and Pollution Research, 22, 1250-1260.

Liu, B., Wang, W. L., Han, R. M., Sheng, M., Ye, L. L., Du, X., Wu, X. T., \& Wang, G. X. (2016a). Dynamics of dissolved oxygen and the affecting factors in sediment of polluted urban rivers under aeration treatment. Water, Air, and Soil Pollution, 227, 172.

Liu, T., Zhang, Z., Mao, Y., \& Yan, D. Y. S. (2016b). Induced metal redistribution and bioavailability enhancement in contaminated river sediment during in situ biogeochemical remediation. Environmental Science and Pollution Research, 23(7), 6353-6362. doi: 10.1007/s11356-015-5842-3
Nykanen, A., Kontio, H., Klutas, O., Penttinen, P., Kostia, S., Mikola, J., \& Romantschuk, M. (2012). Increasing lake water and sediment oxygen levels using slow release peroxide. Sci Total Environ, 429, 317-324.

Perelo, L. W. (2010). Review: in situ and bioremediation of organic pollutants in aquatic sediments. Journal of Hazardous Materials, 177, 81-89.

Sohngen, N. L. (1913). Benzin, petroleum, paraffinol und paraffin als kohlenstoff- und energiequelle für mikroben. Zentr Bakteriol Parasitenk, 37, 595-609.

Solvay, 2012. http://www.solvay.com/en/binaries/R5\%20Brochure\%20 IXPER\%20(2)-284205.pdf, accessed at 3-30-2012.

Veetil, D. P., Mercier, G., Blais, J. F., Chartier, M., \& Tran, L. H. (2013). Simultaneous removal of $\mathrm{Cu}$ and $\mathrm{PAHs}$ from dredged sediments using flotation. Journal of Soils and Sediments, 13, 1502-1514.

Wang, S. R., Jin, X. C., Pang, Y., Zhao, H. C., \& Zhou, H. N. (2005). The study on the effect of $\mathrm{pH}$ on phosphate sorption by different trophic lake sediments. J. Colloid. Interf. Sci., 285, 448-457.

Wu Q, Zhang R, Huang S, Zhang H. 2008. Effects of bacteria on nitrogen and phosphorus release from river sediment.. J Environmental Sciences 20:404-412.

Wu, H., Li, W., Zhang, J., Li, C., Zhang, J., \& Xie, H. (2012). Application of using surface constructed wetland for removal of chemical oxygen demand and ammonium in polluted river water. Desalination Water Treat, 44, 142-150.

Zhang, T. X., Wang, X. R., \& Jin, X. C. (2007). Variations of alkaline phosphatase activity and $P$ fractions in sediments of a shallow Chinese eutrophic lake (lake Taihu). Environmental Pollution, 150(2), 288-294.

Zhang, L., Wang, S. R., \& Wu, Z. H. (2014). Coupling effect of pH and dissolved oxygen in water column on nitrogen release at water sediment interface of Erhai Lake, China. Estuarine, Coastal and Shelf Science, 149, 178-186.

Zhang, Z., Lo, I. M. C., Zheng, G., Woon, K. S., \& Rao, P. (2015). Effect of autotrophic denitrification on nitrate migration in sulfide-rich marine sediments. Journal of Soils and Sediments, 15, 1019. doi: 10.1007/s11368-015-1078-6 .

\section{Submit your next manuscript to BioMed Central and we will help you at every step:}

- We accept pre-submission inquiries

- Our selector tool helps you to find the most relevant journal

- We provide round the clock customer support

- Convenient online submission

- Thorough peer review

- Inclusion in PubMed and all major indexing services

- Maximum visibility for your research

Submit your manuscript at www.biomedcentral.com/submit
) Biomed Central 